\title{
Deforestation and economic growth trends on oceanic islands highlight the need for meso-scale analysis and improved mid-range theory in conservation
}

\author{
Nitin Bhatia ${ }^{1}$ and Graeme S. Cumming ${ }^{1}$
}

\begin{abstract}
Forests both support biodiversity and provide a wide range of benefits to people at multiple scales. Global and national remote sensing analyses of drivers of forest change generally focus on broad-scale influences on area (composition), ignoring arrangement (configuration). To explore meso-scale relationships, we compared forest composition and configuration to six indicators of economic growth over 23 years (1992-2015) of satellite data for 23 island nations. Based on global analyses, we expected to find clear relationships between economic growth and forest cover. Eleven islands lost 1 to $50 \%$ of forest cover, eight gained 1 to $28 \%$, and four remained steady. Surprisingly, we found no clear relationship between economic growth trends and forest-cover change trajectories. These results differ from those of global land-cover change analyses and suggest that conservation-oriented policy and management approaches developed at both national and local scales are ignoring key meso-scale processes.
\end{abstract}

Key Words: deforestation; economic indicators; land-cover change; land-use change; landscape composition; landscape configuration; remote sensing

\section{INTRODUCTION}

Forests support many species and provide a wide range of economically and culturally valuable goods and services. Their role in carbon sequestration and storage, for instance, is globally significant (Molotoks et al. 2018). Global analyses suggest that overall, there is a trend toward shrinking and degradation of forests (Achard et al. 2002, Hansen et al. 2013, Curtis et al. 2018, Song et al. 2018) and increasing forest fragmentation (Kasperson et al. 1995, Turner et al. 2001a, Nagendra et al. 2003, Fearnside 2005). However, reforestation (the return of deforested locations to forest, whether by planting or regeneration) has occurred extensively in some areas (e.g., North America), and time series of forest cover change show high variation and uncertainty in deforestation and reforestation rates (Angelsen 2001).

Deforestation is driven by a range of proximate and ultimate causes that depend on both geographical and historical contexts (Geist and Lambin 2002). Curtis et al. (2018) attributed 27\% of permanent global forest loss to commodity production, with additional losses primarily due to forestry (26\%), shifting agriculture $(24 \%)$, and wildfire $(23 \%)$. Their analysis suggests a clear divide between developed and developing nations ("the global south"), with most commodity-driven deforestation and shifting agriculture occurring in developing nations in Latin America and Asia. However, the many different, interacting variables that drive forest loss make it challenging to understand, govern, and manage (Angelsen 2001, Geist and Lambin 2002). Broad-brush analyses gloss over complexities and feedbacks at a variety of different spatial and governance scales. Global analyses have also focused heavily on measures of landscape composition (amount of habitat or land cover) and have largely ignored changes in landscape configuration (arrangement of habitat or land cover, which, in a land-cover context, refers to the relative position and dispersion of different land-cover types). The importance of habitat configuration for deforestation has been widely explored in individual cases at finer spatial scales (e.g., Laurance et al. 2002, Perz et al. 2008, Lorena and Lambin 2009,
Cumming et al. 2012), but is poorly connected to the understanding of global trends.

Several hypotheses that seek to explain changes in forests relative to wealth have been proposed. First, forest transition theory proposes that a decline in forest cover during industrialization is followed by an increase in forest cover, possibly with a substantial lag, after sufficient wealth has been accumulated (Mather 1992, 2001). Second, researchers have attempted to apply the environmental Kuznets curve (EKC; Kuznets 1955) to forests and have used it to argue that forest loss will follow a U-shaped curve in relation to economic growth. These theories propose a similar trend but different underlying mechanisms. Forest transition theory invokes a mechanism of agricultural adjustment to land quality, relying on the argument that over time, agricultural production will become focused in smaller areas of better land, with poorer land being abandoned and experiencing forest regeneration (Mather and Needle 1998). By contrast, the EKC proposes that as societies become wealthier, they invest more heavily in environmental protection and improvement, again leading to expansion of forests. Substantial concerns have, however, been raised about both of these theories. Perz (2007) has argued that forest transition theory is limited in its concept of what forests are, its treatment of forest dynamics, its explanation for forest transitions, and its generalizability. Similarly, bar a few exceptions mainly relating to pollution, the EKC has been shown to be unsuited to a wide range of environmental problems (Dasgupta et al. 2002, Stern 2004), and an extensive metareview across 76 developing nations found little support for its application to forests (Koop and Tole 1999). In general, while no one denies that changes in forest cover are nonlinear and complex, there appears to be little consensus over singular mechanistic explanations for either deforestation or reforestation (Angelsen and Kaimowitz 1999, Chowdhury and Moran 2012) and a strong need for greater awareness of context dependence in forest-cover dynamics (Perz 2007). 
Context dependence is particularly evident in the choice of scale of land-cover change studies. Local analyses are often highly detailed, achieving specific explanations but lacking in general applicability. By contrast, global analyses extract more predictable and more consistent broad-scale patterns but often fail to explain their underlying mechanisms (Levin 1992). We propose that there is a need for mid-range analyses of both pattern and process in forest-cover trends, meeting recent calls for the development of more strongly contextualized ("midrange") theory (Meyfroidt et al. 2018) that connects fine-scale detail and broad-scale pattern.

We thus addressed the gap between global and local analyses of deforestation by exploring the potential of oceanic islands as mesocosms for understanding global deforestation patterns. We use "meso-scale" to refer to a scale of analysis that falls between global or continental analyses and local analyses, where "local" refers to the area that is regularly accessed by a single community. The island areas that we describe as meso-scale range from 4400 ha to $1.9 \times 10^{8}$ ha. Because of the general lack of comparative, meso-scale analyses and mid-range theories in the published literature, we could not use existing theories to select case studies a priori. Our broader goal for this analysis was thus to use pattern analysis to explore trends within a mid-level, mid-scale set of cases that, in turn, can contribute to the development of contextualized, mid-range theory through the creation of typologies of forest change that reflect the range of causes that can produce a given pattern.

Most oceanic island nations (and inhabited oceanic islands governed by mainland countries) are small $\left(<10,000 \mathrm{~km}^{2}\right)$ and topographically, ecologically, and socially heterogeneous landscapes. Their clear boundaries make estimations of imports and exports simple, and their size means that resource limitation is obvious earlier than in larger systems, providing insights into the landscape-level consequences of global phenomena such as migration and overpopulation. Islands have been proposed as ideal proxies for the study of landscape fragmentation at a global scale (Lugo 2002) and have informed the understanding socialecological resilience in general (MacArthur and Wilson 1963, Lugo 2002, Warren et al. 2015, Patiño et al. 2017). However, there have been few quantitative, comparative studies of landcover change across islands.

We looked at changes in both landscape composition and landscape configuration across 23 different islands. To keep this first meso-scale analysis comprehensible, we limited our analyses to six key economic drivers that might explain the relationship between the level of economic development of a country and changes in forest cover. Based on the results of global analyses (e.g., Curtis et al. 2018), we expected to find (1) a clear distinction in deforestation rates and the pattern of deforestation between developed and less developed nations, with national economies strongly correlated with deforestation rates; and (2) clear connections between economic indicators and the pattern of landscape change because forest clearing for agriculture and commodity production (e.g., pulp and paper) typically follows a different pattern from forest clearing for forestry or by wildfire (Henders et al. 2015).

\section{METHODS}

\section{Data description}

Multisensor Earth observation satellite data were used to quantify changes in global forest cover from 1992-2015 at a spatial resolution of $300 \mathrm{~m}$ for 23 island nations: Andaman and Nicobar, Antigua and Barbuda, Bahamas, Cuba, Cyprus, Dominican Republic, Fiji, Haiti, Indonesia, Jamaica, Japan, Martinique, Mauritius, Philippines, Papua New Guinea (PNG), Puerto Rico, Singapore, Solomon, Sri Lanka, Taiwan, Tasmania, Vanuatu, and Zanzibar. These islands constitute the largest sample size for which we could find reliable, consistent data across a sufficient range of variables. They span a wide range of social, ecological, and economic conditions, including both temperate and tropical ecosystems, and a wide range of different policies and governance. They thus offer good proxies for the study of landscape fragmentation at a global scale.

We used global land-cover data generated under the Climate Change Initiative (Santoro et al. 2017). Data were derived from multisensor time series of Advanced Very High Resolution Radiometer (AVHRR) 7-day composite images, Medium Resolution Imaging Spectrometer (MERIS) full-resolution 7-day composites, and (for 2014 and 2015) Project for On-board Autonomy-Végétation (PROBA-V) 7-day composites. The annual land-cover maps were derived from unique baseline landcover maps generated from the MERIS full-resolution and reduced-resolution archive from 2003 to 2012 (Table 1) and grouped into six broad land categories: cropland, forest, grassland, wetland, settlement, and other land (Table S.1 in Appendix 1). In addition, land cover was measured at $1 \mathrm{~km}$ from the AVHRR time series for the period 1992 to 1999, SPOT-VGT time series for the period 1999 and 2013, and PROBA-V data for years 2013, 2014, and 2015. When MERIS full-resolution or PROBA-V time series were available, changes detected at $1 \mathrm{~km}$ were rescaled at $300 \mathrm{~m}$. The last step consisted of back- and updating the 10 -year baseline land-cover map to produce 24 annual land-cover maps from 1992 to 2015.

\section{Measurement of landscape fragmentation}

We measured land-cover change over time in the area (composition) and arrangement (configuration) of forest habitats, using FRAGSTATS (McGarigal et al. 2012) to quantify metrics at class and landscape levels. Metrics included measures of contrast, shape complexity, aggregation, and isolation (Table 2). Formal definitions are available in Turner et al. (2001b) and McGarigal et al. (2012).

To correct for differences in the magnitudes of different metrics, we standardized the landscape metrics for each of the 30 islands by subtracting the mean and dividing by the standard deviation for that metric. Using the standardized values of each metric (Table 2), we performed three sets of analyses to explore changes in forest composition and configuration within and between islands. The analyses included: (1) quantification and betweenisland comparisons of overall change in forest cover between 1992 and 2015; (2) comparison of trajectories of forest-cover change among islands; and (3) assessment of the similarities and dissimilarities among islands in relation to gross domestic product (GDP). 
Table 1. Data sources used to generate the global land cover maps from 1992-2015, following the methods of Lamarche et al. (2017).

\begin{tabular}{|c|c|c|}
\hline Output map & Reference period & Sensor \\
\hline Baseline 10-yr global land-cover map & $2003-2012$ & - MERIS SR composites \\
\hline Global annual land-cover maps & 1992-1999 & $\begin{array}{l}\text { - Baseline 10-yr global land-cover map } \\
\text { - AVHRR global SR composites for back-dating the baseline }\end{array}$ \\
\hline Global annual land-cover maps & 1999-2013 & $\begin{array}{l}\text { - Baseline 10-yr global land-cover map } \\
\text { - SPOT-VGT global SR composites for up- and back-dating the baseline for the } \\
\text { reference period } \\
\text { - MERIS FR global SR composites between } 2003 \text { and } 2012 \text { to delineate the maps at } \\
300 \mathrm{~m} \\
\text { - PROBA-V global SR composites at } 300 \mathrm{~m} \text { for } 2013 \text { to delineate the maps }\end{array}$ \\
\hline Global annual land-cover maps & 2014-2015 & $\begin{array}{l}\text { - Baseline 10-yr global land-cover map } \\
\text { - PROBA-V global SE composites at } 1 \mathrm{~km} \text { between } 2014 \text { and } 2015 \text { for updating the } \\
\text { baseline } \\
\text { - PROBA-V time series at } 300 \mathrm{~m} \text { for years } 2014 \text { and } 2015 \text { to delineate the maps to } \\
300 \mathrm{~m}\end{array}$ \\
\hline
\end{tabular}

Table 2. Description and interpretation of landscape composition and configuration characteristics quantified at class and landscape level.

\begin{tabular}{|c|c|c|c|c|}
\hline Metric & Acronym & Ecological interpretation & Units & Calculation method \\
\hline Edge density & ED & $\begin{array}{l}\text { Measure of edge, corrected for area; forest edges } \\
\text { can influence many ecologically relevant processes } \\
\text { such as the spread of fire, dispersal, and predation } \\
\text { (Cadenasso et al. 1997, Cadenasso and Pickett } \\
\text { 2000) }\end{array}$ & $\mathrm{m} / \mathrm{ha}$ & $\begin{array}{l}\text { Sum of the lengths }(\mathrm{m}) \text { of all edge segments } \\
\text { involving the corresponding class type, } \\
\text { divided by the total landscape area (ha) }\end{array}$ \\
\hline $\begin{array}{l}\text { Mean Euclidean } \\
\text { nearest-neighbor } \\
\text { distance }\end{array}$ & ENN_MN & $\begin{array}{l}\text { Measure of isolation, which is important for } \\
\text { dispersal and patch recolonization }\end{array}$ & $\mathrm{m}$ & $\begin{array}{l}\text { Shortest straight-line distance }(\mathrm{m}) \text { between a } \\
\text { focal patch and its nearest neighbor of the } \\
\text { same class }\end{array}$ \\
\hline $\begin{array}{l}\text { Percentage of } \\
\text { landscape }\end{array}$ & PLAND & $\begin{array}{l}\text { Measure of composition (relative cover), which } \\
\text { affects resource availability, competition, and alpha } \\
\text { (local) diversity }\end{array}$ & $\%$ & $\begin{array}{l}\text { Proportional abundance of each patch type } \\
\text { in the landscape }(0<\text { PLAND } \leq 100)\end{array}$ \\
\hline $\begin{array}{l}\text { Mean fractal } \\
\text { dimension index }\end{array}$ & FRAC_MN & $\begin{array}{l}\text { Measure of shape complexity, which influences } \\
\text { dispersal, predation, and edge effects }\end{array}$ & None & $\begin{array}{l}\text { Shape index based on perimeter:area } \\
\text { relationships in which the perimeter and } \\
\text { area are log transformed }\end{array}$ \\
\hline Clumpy index & CLUMPY & $\begin{array}{l}\text { Measure of aggregation; CLUMPY is the only } \\
\text { aggregation index that is independent of landscape } \\
\text { composition (measured by PLAND as relative } \\
\text { forest cover) and is unaffected by the shape of the } \\
\text { landscape; it captures the degree to which habitats } \\
\text { are aggregated or dispersed, which has } \\
\text { consequences for dispersal, predation, } \\
\text { reproduction, and metapopulation dynamics }\end{array}$ & $\%$ & $\begin{array}{l}\text { Proportional deviation of the proportion of } \\
\text { like adjacencies involving the corresponding } \\
\text { class from that expected under a spatially } \\
\text { random distribution }(-1 \leq \text { CLUMPY } \leq 1)\end{array}$ \\
\hline Aggregation index & AI & $\begin{array}{l}\text { Level of aggregation of spatial patterns; like } \\
\text { CLUMPY, aggregation has consequences for } \\
\text { metapopulation and ecological community } \\
\text { dynamics }\end{array}$ & $\%$ & $\begin{array}{l}\text { Number of like adjacencies involving the } \\
\text { corresponding class, divided by the } \\
\text { maximum possible number of like } \\
\text { adjacencies involving the corresponding } \\
\text { class }\end{array}$ \\
\hline
\end{tabular}

The first set of analyses used the PLAND metric (Table 2) to quantify net loss or gain in forest cover between the years 1992 and 2015 using the standard percentage change relation. A range of terms quantified is given in Table 3 . We used percentage change because the islands exhibited considerable variance in area, and many metrics of forest composition and configuration are scale dependent. Importantly, net percentage change does not reflect variance in the rate of land-cover change or other properties of the change trajectory. Our second set of analyses thus considered forest dynamics using time series data that require the pattern and random components to be identified to obtain uncorrelated data points in time. We determined that values were uncorrelated at a lag of 5 years using the autocorrelation function "acf" in the "Stat" package of R (R Core Team). For this analysis, we thus divided the total period of 24 years into four subperiods (minimum of 5 years): 1992-1997, 1997-2002, 2002-2007, and 2007-2015.

We selected key economic indicators for linking economic growth and environmental sustainability based on standard economic growth theories that suggest connections between wealth, labor, capital, environmental stocks, and human well-being (e.g., Schumpeter 1983, Solow 1956, Swan 1956, Chenery et al. 1986, Lin and Rosenblatt 2012). We focused on five variables that have been strongly implicated as relevant to development trajectories by Cumming and von Cramon-Taubadel (2018): population growth, GDP (GDP per capita [constant local currency unit]), forest rents, the Human Development Index (HDI), and the value added by agriculture (\%GDP). These data were obtained from the World Bank Open Data Set (https://data.worldbank.org/). 
Table 3. Definitions of terms used to refer to changes in forest cover in the analyses and results. See Table 2 for definition of variable acronyms.

\begin{tabular}{ll}
\hline \hline Term & Definition and determination \\
\hline $\begin{array}{l}\text { Prior forest cover } \\
\text { Net percentage change in forest } \\
\text { cover }\end{array}$ & $\begin{array}{l}\text { Forest cover (total area, as measured through PLAND) of an island in 1992 } \\
\text { First, the net change in forest cover between } 1992 \text { and 2015 was calculated for each individual island as the sum of all } \\
\text { changes in PLAND over 1992-2015 (including reductions due to deforestation and disasters and increases due to } \\
\text { reforestation and forest expansion); then, we divided the net change in forest cover by prior forest cover and multiplied } \\
\text { this fraction by } 100 \text { to give the net percent change in forest cover }\end{array}$ \\
A positive net change in forest cover \\
$\begin{array}{l}\text { Net forest cover gain } \\
\text { Mean change in net forest cover }\end{array}$ & $\begin{array}{l}\text { The sum of net percentage change in forest cover of all 23 islands divided by 23 gives a mean change in net forest cover } \\
\text { across all islands; the standard deviation of this value measures variability in net percentage change in forest cover }\end{array}$ \\
\hline
\end{tabular}

National economies are essentially bimodal, with less financially wealthy nations (those with HDI $=4$ ) and more financially wealthy nations (HDI $=1$ ) tending toward two different socialecological attractors (Cumming and von Cramon-Taubadel 2018). HDI $=4$ nations depend proportionally more heavily and more directly on natural resources and agriculture and experience lower GDP with increased population growth. Simplistically, one might thus expect that higher population growth rate in HDI = 4 nations leads to greater levels of deforestation, whereas in HDI $=1$ countries, higher population growth rate leads to a higher GDP (as a consequence, for example, of technological and service industries) and, potentially, a reduced direct reliance on ecosystems and lower deforestation rates. However, a series of complex feedbacks means that the relationship between different indicator variables and deforestation itself is not necessarily consistent.

We tested for correlations between forest-cover change using composition and configuration matrices and matching economic data. Our third set of analyses used Mantel tests with the nonparametric Spearman's method in the "vegan" package in R (Dixon 2003). The Mantel test was performed using data points (for both ecological matrices [composition and configuration] and economic growth drivers) that were uncorrelated in time, i.e., for the four subperiods only. The Mantel test takes dissimilarity matrices as input arguments; these matrices were calculated using the "vegdist" function in the vegan package with default arguments. For the Mantel test using population growth GDP per capita data, 21 islands were included. For forest rents, data from 20 islands were available, and for agriculture value ( $\%$ GDP) and HDI drivers, data from 19 islands were available.

In our fourth set of analyses, we first grouped islands by forestcover change (both composition and configuration) and then tested for a relationship between forest-cover change group membership and GDP. To check for the possible statistical bias that might emerge if smaller islands have weaker economies, we also tested for a correlation between GDP and island area using standardized landscape metrics and proportions. Grouping used an unsupervised, two-fold, hierarchical clustering approach to calculate dissimilarity metrics for each island using a time series clustering approach (the "diss" function in the "TSclust" library in R; Montero and Vilar 2014). TSclust corrects for the timedependent component, so we used data from the entire study period (not subperiods) to create groups. Next, for each metric, we performed hierarchical clustering using Ward's minimum variance method to assign cluster membership to each island based on an optimal value of the objective function (error sum of squares). The option "ward.D2" was used because it minimizes the Ward's minimum criterion more efficiently than does the "ward.D" method (Murtagh and Legendre 2014). The dendogram clustering was based on the pairwise dissimilarities and the number of groups for cutting the tree $(k=4)$ and the height arguments of the "fviz_dend" function of the package "factoextra" in R (Kassambara and Mundt 2017). Finally, to check for an effect of absolute island area on variables of interest, we compared island area, population growth and change, and total forest area (in ha) and change in forest area (using the data in Table 4). Summary data for the economic variables, forest rents ( $\%$ GDP), agriculture (and forestry and fishing) value added ( $\%$ GDP), and HDI with forest cover for each island are given in Appendix 1 (Table S.2).

\section{RESULTS}

The mean change in net forest cover across all islands was $-3.14 \%$ $\pm 15 \%$. The range of net forest cover loss was approximately -50 to $-1 \%$ by area, and the range of net forest cover gain was approximately 1 to $28 \%$ (Fig. 1), determined from percentage net forest change (Fig. A.1 in Appendix 1). Eleven islands experienced net forest cover loss (i.e., $<-1.0 \%$ ), eight experienced net forest cover gain (i.e., $>+1.0 \%$ ), and net forest cover for four islands remained steady (between -0.22 and $0.90 \%$ ), indicating the complexities of deforestation and reforestation dynamics occurring within the study data (formal definitions of mean change in forest cover and related terminology are given in Table $3)$.

Analysis of change trajectories across the four subperiods revealed similarly complex patterns in landscape composition and configuration over time (Fig. 2). For illustration, we have used the change trajectories of Japan, Singapore, and PNG; these islands were grouped together by forest-cover metrics (Fig. 3) and other configuration metrics. For these islands, even though the net change in forest cover remained low $(-3.5$ to $+3.5 \%)$, the landscape configuration changed significantly, with potentially important implications for ecological processes that depend on connectivity. For example, net forest cover change for Japan between 1992 and 2015 was low $(+0.26 \%)$, and time-series analysis showed that forest patch complexity and edge length remained steady (largest increase approximately $0.20 \%$ in shape and 
Table 4. Total area, population size, change in population, total forested area, and change in forested area on each island examined to determine if pressure from the population influences forested area.

\begin{tabular}{|c|c|c|c|c|c|c|c|c|c|c|}
\hline \multicolumn{2}{|c|}{ Island } & \multicolumn{3}{|c|}{ Total population } & \multicolumn{3}{|c|}{ Forest area $(\mathrm{CA} ;$ ha $)$} & \multicolumn{3}{|c|}{ Maximum CA change } \\
\hline Name & Area (ha) & 1992 & 2015 & $\begin{array}{c}\text { Change } \\
(\%)\end{array}$ & CA (1992) & CA (2015) & $\begin{array}{c}\text { Change } \\
(\%)\end{array}$ & $\mathrm{CA}$ & Year & Change $(\%)$ \\
\hline $\begin{array}{l}\text { Anadaman and } \\
\text { Nicobar }\end{array}$ & 825,000 & No data & 400,112 & No data & $649,656.27$ & $646,692.39$ & -0.46 & $656,227.9$ & 1996 & 1.01 \\
\hline $\begin{array}{l}\text { Antigua and } \\
\text { Barbuda }\end{array}$ & 44,000 & 64,471 & 93,566 & 45.13 & $18,512.32$ & $18,093.25$ & -2.26 & $19,860.66$ & 2009-2013 & 7.28 \\
\hline Bahamas & $1,387,800$ & 266,029 & 374,206 & 40.66 & $525,287.20$ & $565,646.30$ & 7.68 & $567,134.3$ & 2010 & 7.97 \\
\hline Cuba & $10,988,400$ & $10,736,387$ & $11,324,781$ & 5.48 & $4,383,321.32$ & $4,566,774.33$ & 4.19 & $4,570,880.08$ & 2010 & 4.28 \\
\hline Cyprus & 925,100 & 800,611 & $1,160,985$ & 45.01 & $180,428.36$ & $190,419.43$ & 5.54 & $190,419.43$ & 2014-2015 & 5.54 \\
\hline $\begin{array}{l}\text { Dominican } \\
\text { Republic }\end{array}$ & $4,844,200$ & $7,408,342$ & $10,281,680$ & 38.78 & $1,997,515.08$ & $2,312,929.14$ & 15.79 & $2,325,525.78$ & 2010 & 16.42 \\
\hline Fiji & $1,833,300$ & 744,469 & 868,627 & 16.68 & $1,275,352.20$ & $1,255,321.48$ & -1.57 & $1,255,321.48$ & 2014-2015 & -1.57 \\
\hline Haiti & $2,775,000$ & $7,319,493$ & $10,695,542$ & 46.12 & $392,020.34$ & $391,097.16$ & -0.24 & $415,719.5$ & 2004 & 6.05 \\
\hline Indonesia & $190,456,900$ & $258,383,256$ & $187,739,786$ & -27.34 & $92,778,372.91$ & $109,441,597.15$ & 17.96 & $115,702,820$ & 1993-2000 & 24.71 \\
\hline Jamaica & $1,099,200$ & $2,461,049$ & $2,891,021$ & 17.47 & $873,996.74$ & $780,378.31$ & -10.71 & $780,378.31$ & 2015 & -10.71 \\
\hline Japan & $37,791,500$ & $125,331,291$ & $127,985,133$ & 2.12 & $26,054,153.73$ & $25,346,524.97$ & -2.72 & $25,346,524.97$ & 2015 & -2.72 \\
\hline Martinique & 112,800 & 362,757 & 378,478 & 4.33 & $81,823.50$ & $81,404.43$ & -0.51 & $81,404.43$ & 2015 & -0.51 \\
\hline Mauritius & 204,000 & $1,082,956$ & $1,259,456$ & 16.30 & $76,952.47$ & $52,026.43$ & -32.39 & $52,026.43$ & 2015 & -32.39 \\
\hline Philippines & $30,000,000$ & $65,020,116$ & $102,113,212$ & 57.05 & $12,746,950.41$ & $13,302,356.60$ & 4.36 & $13,302,775.67$ & 2014 & 4.36 \\
\hline $\begin{array}{l}\text { Papua New } \\
\text { Guinea }\end{array}$ & $46,284,000$ & $4,836,217$ & $8,107,775$ & 67.65 & $39,635,914.03$ & $39,273,520.70$ & -0.91 & $38,638,884.42$ & 2000 & -2.52 \\
\hline Puerto Rico & $1,380,000$ & $3,469,068$ & $3,381,518$ & -2.52 & $525,596.97$ & $578,935.30$ & 10.15 & $587,869.56$ & 2009 & 11.85 \\
\hline Singapore & 72,150 & $3,199,642$ & $5,592,152$ & 74.78 & $12,596.64$ & 8667.02 & -31.20 & 8667.02 & 2015 & -31.20 \\
\hline Solomon & $2,839,900$ & 329,995 & 603,118 & 82.76 & $2,692,243.52$ & $2,700,078.46$ & 0.29 & $2,705,035$ & 2008 & 0.48 \\
\hline Sri Lanka & $6,561,000$ & $17,736,821$ & $20,908,027$ & 17.88 & $2,573,668.68$ & $2,317,502.56$ & -9.95 & $2,279,645.82$ & 2004 & -11.42 \\
\hline Taiwan & $3,619,300$ & $20,868,148$ & $23,557,477$ & 12.89 & $2,276,092.77$ & $2,196,941.65$ & -3.48 & $2,196,941.65$ & 2015 & -3.48 \\
\hline Tasmania & $6,840,100$ & 474,224 & 516,600 & 8.93 & $5,447,865.03$ & $5,360,824.30$ & -1.60 & $5,311,537.06$ & 2000 & -2.50 \\
\hline Vanuatu & $1,219,900$ & 155,170 & 271,130 & 74.73 & $887,030.68$ & $1,138,101.05$ & 28.30 & $1,138,101.04$ & 2014-2015 & 28.30 \\
\hline Zanzibar & 246,100 & 350,000 & No data & No data & $24,598.07$ & $26,092.17$ & 6.07 & $28,843.51$ & 2004 & 17.26 \\
\hline
\end{tabular}

Fig. 1. Net percentage change in forest cover for each island studied. The mean change in net forest cover across all islands was $-3.132 \%$, indicated by the dotted line.

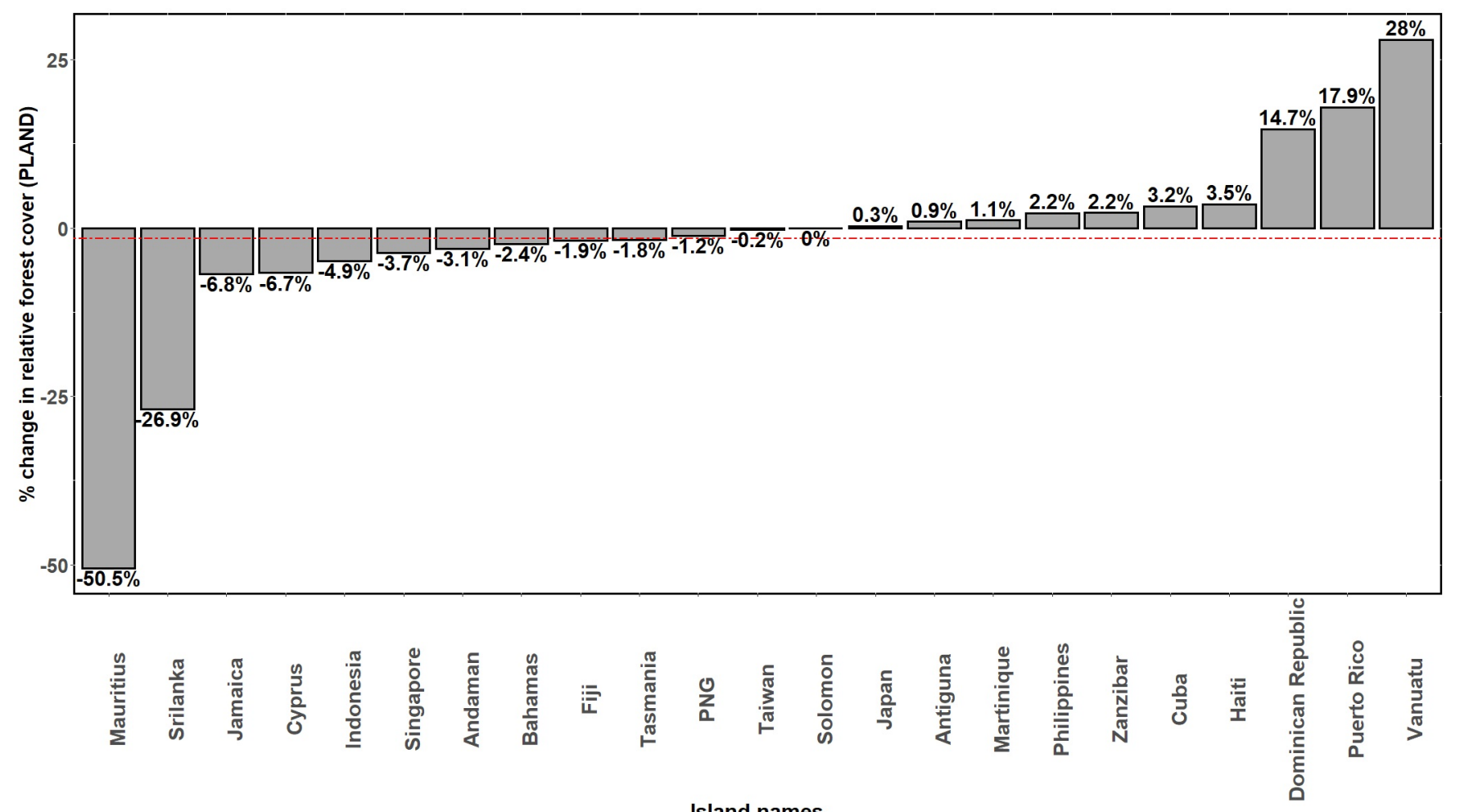

Island names 
Fig. 2. Change trajectories of six net forest-cover metrics for three example islands (Japan, Singapore, and Papua New Guinea) over the four subperiods of our analysis from 1992-2015. These islands were grouped together in their forest-cover metrics (Fig. 3). This figure shows that even though the net change in forest cover remained low for some islands, the landscape configuration changed significantly, with potentially important implications for ecological processes that depend on connectivity.
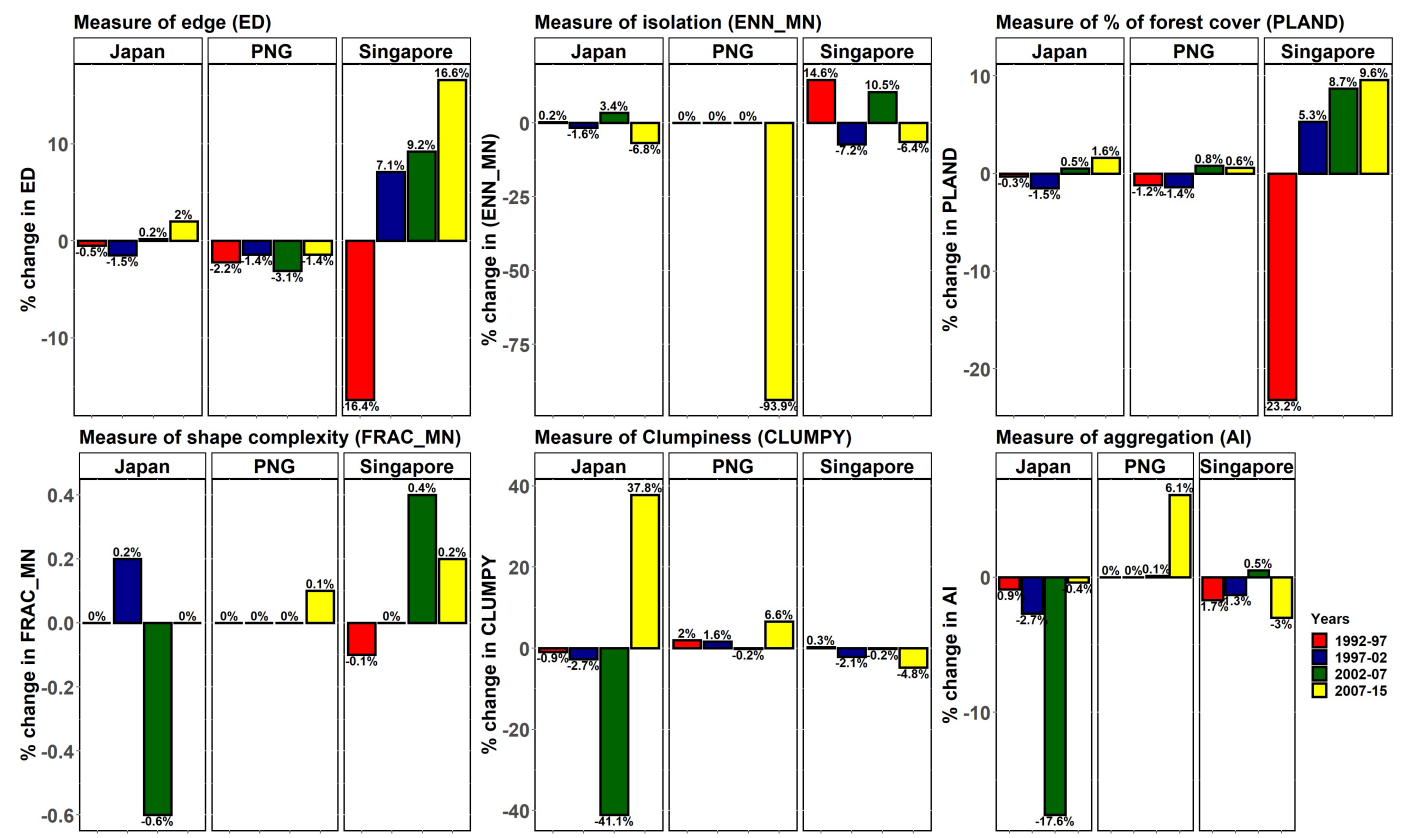

Fig. 3. Dendrogram showing hierarchical clusters that emerged from the relative forest-cover metrics (total area, as measured through percentage of forest cover). The similarities and dissimilarities between islands in relation to forest cover measures emerged as four stable clusters, where cluster members are more similar to one another than to other islands in the sample. This result illustrates the relative irrelevance of national-level gross domestic product as a predictor of trends in island forest composition and configuration. For example, the highly industrialized island of Japan shows similar trends to the much less industrialized nation of Papua New Guinea.

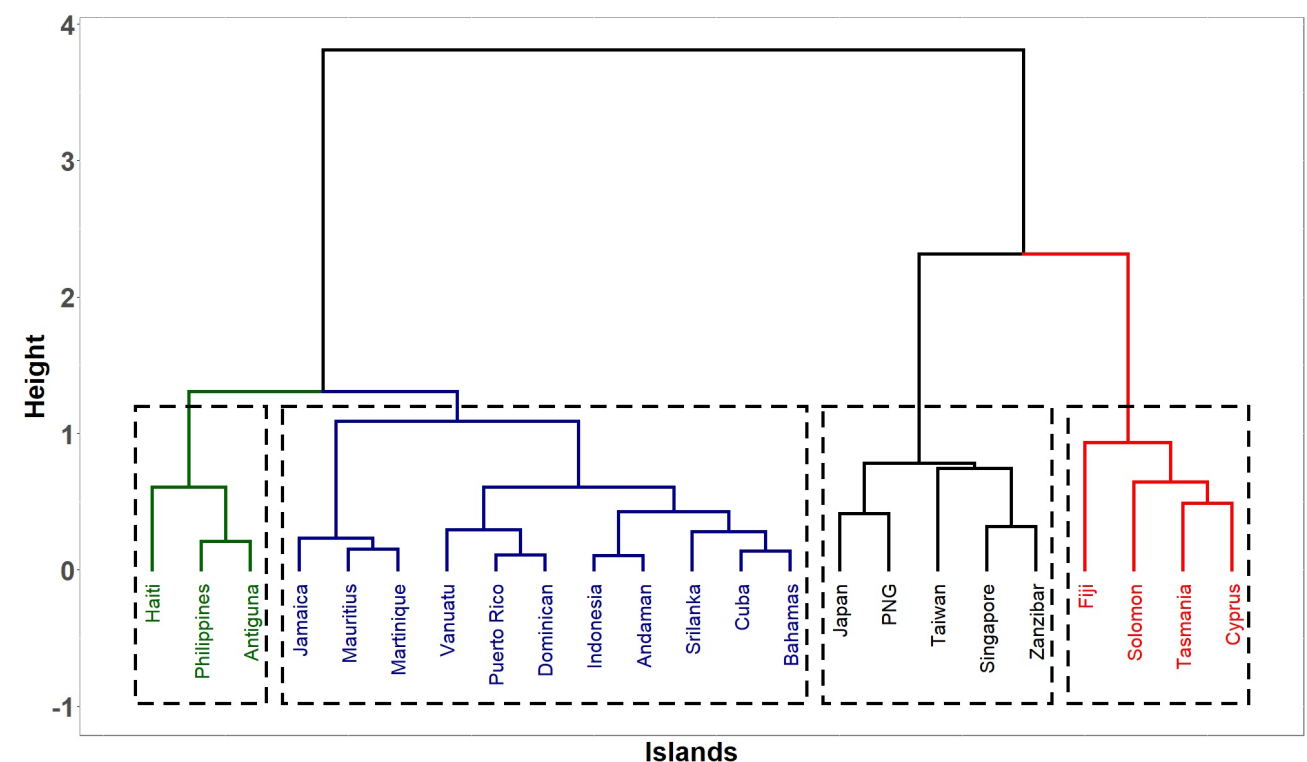

Islands 
Table 5. Results of Mantel test correlations between matrices of landscape composition and configuration metrics and the economic growth drivers. To perform the test, we first produced temporally independent data for each variable and economic driver for each subperiod. Subject-subject dissimilarity matrices were then generated and compared using the Mantel test. Results with $P>0.05$ are considered statistically significant. See Table 2 for metric definitions.

\begin{tabular}{|c|c|c|c|c|c|c|c|c|c|c|}
\hline \multirow[t]{2}{*}{ Metric } & \multicolumn{2}{|c|}{ Population growth } & \multicolumn{2}{|c|}{ Forest rents } & \multicolumn{2}{|c|}{$\begin{array}{c}\text { Gross domestic product } \\
\text { per capita }\end{array}$} & \multicolumn{2}{|c|}{$\begin{array}{l}\text { Human Development } \\
\text { Index }\end{array}$} & \multicolumn{2}{|c|}{ Agriculture value added } \\
\hline & $r$ & $P$ & $r$ & $P$ & $r$ & $P$ & $r$ & $P$ & $r$ & $P$ \\
\hline PLAND & 0.8303 & 0.0167 & 0.8182 & 0.0500 & 0.5030 & 0.0333 & 0.8667 & 0.0167 & 0.8788 & 0.0250 \\
\hline FRAC_MN & 0.7697 & 0.0250 & 0.8303 & 0.0250 & 0.7333 & 0.0166 & 0.9515 & 0.0083 & 0.7697 & 0.0667 \\
\hline ED & 0.7818 & 0.0250 & 0.6970 & 0.0667 & 0.4545 & 0.0667 & 0.9515 & 0.0083 & 0.8545 & 0.0167 \\
\hline CLUMPY & 0.6606 & 0.0416 & 0.8424 & 0.0250 & 0.4303 & 0.0750 & 0.8788 & 0.0083 & 0.8788 & 0.0167 \\
\hline AI & 0.7333 & 0.0333 & 0.7818 & 0.0583 & 0.4424 & 0.0583 & 0.8788 & 0.0167 & 0.9758 & 0.0083 \\
\hline ENN_MN & 0.9030 & 0.0167 & 0.3818 & 0.1167 & 0.7697 & 0.0416 & 0.8667 & 0.0083 & 0.8788 & 0.0083 \\
\hline
\end{tabular}

Table 6. Results of ANOVA tests of the hypothesis that groups based on gross domestic product growth should be the same as the forest-cover change groups. See Table 2 for metric definitions.

\begin{tabular}{|c|c|c|c|c|c|c|}
\hline Metric used for clustering & $\begin{array}{l}\text { Degrees of } \\
\text { freedom }\end{array}$ & Sum of squares & Mean squares & $F$ & $P$ & $\begin{array}{c}\text { Decision on statistical } \\
\text { hypothesis }\end{array}$ \\
\hline \multirow[t]{4}{*}{ PLAND } & 2 & 179.4 & 89.70 & 22.68 & $<0.05$ & Reject \\
\hline & 9 & 678.8 & 75.42 & 5.685 & $<0.05$ & Reject \\
\hline & 5 & 1458 & 291.53 & 20.06 & $<0.05$ & Reject \\
\hline & 3 & 8.2 & 2.723 & 0.182 & $>0.05$ & Support \\
\hline \multirow[t]{4}{*}{ FRAC_MN } & 14 & 1813 & 129.50 & 14.47 & $<0.05$ & Reject \\
\hline & 2 & 199.8 & 99.92 & 4.771 & $<0.05$ & Reject \\
\hline & 1 & 87.6 & 87.55 & 4.082 & $<0.05$ & Reject \\
\hline & 2 & 36.8 & 18.41 & 1.072 & $>0.05$ & Support \\
\hline \multirow[t]{3}{*}{ ED } & 14 & 1173 & 83.78 & 6.898 & $<0.05$ & Reject \\
\hline & 2 & 997.6 & 498.8 & 112.1 & $<0.05$ & Reject \\
\hline & 3 & 144.6 & 48.21 & 3.396 & $<0.05$ & Reject \\
\hline \multirow[t]{4}{*}{ CLUMPY } & 2 & 107.6 & 53.81 & 3.893 & $<0.05$ & Reject \\
\hline & 6 & 404.6 & 67.43 & 3.807 & $<0.05$ & Reject \\
\hline & 5 & 593.2 & 118.64 & 11.73 & $<0.05$ & Reject \\
\hline & 8 & 1520 & 189.97 & 24.11 & $<0.05$ & Reject \\
\hline \multirow[t]{4}{*}{ AI } & 8 & 1680 & 210.06 & 32.05 & $<0.05$ & Reject \\
\hline & 1 & 102.7 & 102.69 & 12.48 & $<0.05$ & Reject \\
\hline & 3 & 184.7 & 61.56 & 3.084 & $<0.05$ & Reject \\
\hline & 7 & 616.8 & 88.12 & 5.175 & $<0.05$ & Reject \\
\hline \multirow[t]{4}{*}{ ENN_MN } & 5 & 912.3 & 182.47 & 19.85 & $<0.05$ & Reject \\
\hline & 4 & 483.7 & 120.92 & 17.34 & $<0.05$ & Reject \\
\hline & 3 & 263.8 & 87.93 & 5.533 & $<0.05$ & Reject \\
\hline & 7 & 630 & 89.96 & 5.218 & $<0.05$ & Reject \\
\hline
\end{tabular}

approximately $2 \%$ in edge; largest decrease $-0.64 \%$ in shape and $-1.53 \%$ in edge). By contrast, both aggregation index and clumpiness changed significantly between 2002 and 2007, with declines of -17.6 and $-41 \%$, respectively. Japan, for example, showed a 37\% increase in clumpiness in the period 2007-2015.

To assess the similarities and dissimilarities between islands in relation to economic variables, we performed Mantel tests using landscape metrics and economic drivers for the corresponding islands. The Mantel test comparing economic variables and mesoscale land use (Table 5) showed that for 4 of 30 instances, the null hypothesis was supported (e.g., forest rents and forest cover had Mantel statistics $r=0.8182$ and $P=0.05$ ); for the others, the null hypothesis was rejected (e.g., comparison of GDP per capita and clumpiness gave $r=0.4303$ and $P=0.0750$ ).

To assess the similarities and dissimilarities between islands in relation to GDP growth, we grouped the islands by similarities in their landscape metrics (Fig. 3). This unsupervised clustering analysis indicated that there were four natural clusters of islands $(k=4)$ for most metrics. Clusters represented groupings of islands that were more similar to each other than to other islands, providing an unbiased taxonomy of islands that was independent of their economic data. Islands did not fall in the same clusters for all metrics, indicating a lack of consistency in their forestcover trajectories. The ANOVA test of whether national economic variables and meso-scale land use were interrelated (Table 6) showed that for 2 of 23 instances, the null hypothesis was supported; for the others, the null hypothesis was rejected. In addition, the correlation between forest area and GDP was weak (Spearman $\rho=-0.19, P<0.37$ ). We thus found no clear relationship between change in forest cover and economic growth.

Finally, comparison of the log of absolute island area to changes in population density, forest area, and forest patch sizes yielded 
no significant correlations $(\mathrm{df}=3$, sums of squares $=8181, F=$ $12, P<0.0001)$, indicating that our results are not an artefact of considering relative rather than absolute changes in forest cover.

\section{DISCUSSION AND CONCLUSION}

In stark contrast with most global deforestation analyses (Achard et al. 2002, Hansen et al. 2008, 2013, DeFries et al. 2010, Song et al. 2018), consideration of forest-cover change patterns and trends at a meso-scale level of analysis did not provide a clear separation of countries based on economic data. We found four broad composition and configuration clusters within geographically and socioeconomically heterogeneous islands with varied forest cover, although the membership of each cluster was not consistent for every forest-related metric. Island groups as defined by forest-cover change contained mixed economic and socioeconomic types and were geographically diverse. These results paint a more complex picture than do coarser global landcover change analyses and suggest strong scale dependence in current understanding of the relationships between forest cover and economic activity. The lack of general trends is intriguing and suggests that important processes and dynamics have not been adequately included in existing theories of deforestation; hence, islands appear to offer an interesting and potentially feasible entry point for further research linking fine- and broadscale drivers of deforestation.

Although local and meso-scale land-use trends are influenced by national and global trends (Geist and Lambin 2002), they may differ substantially from them. For 4 of 30 instances (Mantel test, Table 5) and for 2 of 23 instances (ANOVA test, Table 6), our null hypothesis was supported (e.g., for forest cover), whereas for other instances it was rejected (e.g., for edge density), providing no clear evidence to support a relation between landscape metrics and drivers of economic growth. Forest-cover change and economic growth should be strongly correlated if composition and configuration metrics were directly influenced by economic growth (Crespo Cuaresma et al. 2017), implying that nationallevel economic trends alone are not sufficient to explain deforestation. In simple terms, our data show that wealth alone does not drive forest conservation and that developing countries are not necessarily poor stewards of forests, despite their proportionally higher economic dependence on forests. For larger nations, simplistically comparing national-level economic indicators with deforestation per se through remote sensing ignores the meso-scale dynamics of markets, access, and settlement patterns that can strongly influence forest loss and gain and economic growth patterns. Many authors (Cropper and Griffiths 1994, Angelsen and Kaimowitz 1999, Lykke et al. 2002, DeFries et al. 2010) have highlighted the demographic, policy, and economic factors that contribute to growing demands for agriculture, rangeland, and wood that in turn exert pressure on forests, but the degree to which these influences are relevant across different scales has been less clear. Encouragingly, it appears that effective forest cover can be maintained across a wide variety of national-level economic conditions. Our results thus provide additional novel empirical support for recent calls for stronger development of mid-range, contextualized theory (Magliocca et al. 2018, Meyfroidt et al. 2018).

Configuration metrics describe additional impacts of forest loss and fragmentation on ecological processes and ecosystem services. Despite the ongoing debate in conservation biology about the relative importance of habitat composition and habitat configuration (Fletcher et al. 2018, Fahrig et al. 2019, MillerRushing et al. 2019), there is good evidence that habitat fragmentation matters for a wide range of ecological processes (Cunningham et al. 2015, Haddad et al. 2015). Interestingly, for some islands in our analysis, landscape configuration indices changed much more than composition indices, suggesting subtle differences in the ways in which forests are used. These changes are again largely undetectable at global scales of analysis, supporting the argument that meso-scale analyses of landscape change provide a potentially useful way of linking global and local drivers of change.

Differences in the results obtained by forest-cover analyses at different scales have potentially important consequences for forest policy and conservation efforts. For example, Le et al. (2012) found that most forest conservation policies focus on area planted and initial tree survival for short-term biodiversity restoration or timber production, whereas broader criteria for longer term success and sustainability are ignored. Treby et al. (2014) also found significant gaps between global, national, state, and territorial forest management plans; and Decocq et al. (2016) found that small patches were generally not legally protected against conversion to another land use. Long-term changes in global forest cover are well documented and may be used to design policies governing forest management and land use (e.g., reforestation and afforestation policies).

Looking forward, theory suggests that incongruities between the scales of forest management policy design and implementation can result in poor forest management and conservation (Epstein et al. 2015). Our analysis highlights the point that one of the central questions for efforts to sustainably govern forests will be that of how to align different policies and forest initiatives at different scales (national, regional, and local) in ways that are both effective within scales and consistent across scales. Understanding the drivers of both deforestation and afforestation at different scales will in turn require the deliberate measurement and cross-case comparison of relevant influences on deforestation, ranging from national policies through regional governance structures to local regulations and guidelines. Obtaining these data will require that social scientists in particular step out of their standard paradigm (i.e., in-depth study at a single location) and, instead, compare trends across multiple study locations from different systems that are distinct at regional and national as well as local scales (Cumming et al. 2020). Consideration of islands and the ways in which they can be used to understand how local and national scales of policy are interrelated may thus offer important new insights for developing more effective forest conservation policies.

Responses to this article can be read online at: http://www.ecologyandsociety.org/issues/responses. php/11713

\section{Acknowledgments:}

This research was supported by the ARC Centre of Excellence for Coral Reef Studies and a James S. McDonnell Foundation complexity scholar award to GSC. 


\section{Data Availability Statement:}

The data that support the findings of this study are openly available in world development indicators. The data were obtained from the World Bank Open Data Set (https://data.worldbank.org/). Global land-cover data generated under the Climate Change Initiative are available through http:/lcci.esa.int/content/land-cover-data and following the methods of Santoro et al. (2017). To calculate dendrogram clusters we used the TSClust library in $R$, and for enhanced visualization of dendrograms, we used the factoextra library in $R$. For other calculations and analyses, usual $R$ libraries and packages were used and cited.

\section{LITERATURE CITED}

Achard, F., H. D. Eva, H.-J. Stibig, P. Mayaux, J. Gallego, T. Richards, and J.-P. Malingreau. 2002. Determination of deforestation rates of the world's humid tropical forests. Science 297:999-1002. https://doi.org/10.1126/science.1070656

Angelsen, A. 2001. Deforestation-forestation. Pages 3359-3364 in N. J. Smelser and P. B. Baltes, editors. International Encyclopedia of the Social and Behavioral Sciences. Elsevier, Amsterdam, The Netherlands. https://doi.org/10.1016/B0-08-043076-7/04173-5

Angelsen, A., and D. Kaimowitz. 1999. Rethinking the causes of deforestation: lessons from economic models. World Bank Research Observer 14(1):73-98. [online] URL: https://documents. worldbank.org/en/publication/documents-reports/ documentdetail/264451468180276699/rethinking-the-causes-ofdeforestation-lessons-from-economic-models

Cadenasso, M. L., and S. T. A. Pickett. 2000. Linking forest edge structure to edge function: mediation of herbivore damage. Journal of Ecology 88(1):31-44. https://doi.org/10.1046/ j.1365-2745.2000.00423.x

Cadenasso, M. L., M. M. Traynor, and S. T. A. Pickett. 1997. Functional location of forest edges: gradients of multiple physical factors. Canadian Journal of Forest Research 27(5):774-782. https://doi.org/10.1139/x97-013

Chenery, H. B., S. Robinson, and M. Syrquin. 1986. Industrialization and growth: a comparative study. Oxford University Press, Oxford, UK. [online] URL: https://documents. worldbank.org/en/publication/documents-reports/

documentdetail/714961468135943204/industrialization-and-growtha-comparative-study

Chowdhury, R. R., and E. F. Moran. 2012. Turning the curve: a critical review of Kuznets approaches. Applied Geography 32 (1):3-11. https://doi.org/10.1016/j.apgeog.2010.07.004

Crespo Cuaresma, J., O. Danylo, S. Fritz, I. McCallum, M. Obersteiner, L. See, and B. Walsh. 2017. Economic development and forest cover: evidence from satellite data. Scientific Reports 7:40678. https://doi.org/10.1038/srep40678

Cropper, M., and C. Griffiths. 1994. The interaction of population growth and environmental quality. American Economic Review 84 (2):250-254.

Cumming, G. S., G. Epstein, J. M. Anderies, C. I. Apetrei, J. Baggio, Ö. Bodin, S. Chawla, H. S. Clements, M. Cox, L. Egli, G. G. Gurney, M. Lubell, N. Magliocca, T. H. Morrison, B. Müller,
R. Seppelt, M. Schlüter, H. Unnikrishnan, S. Villamayor-Tomas, and C. M. Weible. 2020. Advancing understanding of natural resource governance: a post-Ostrom research agenda. Current Opinion in Environmental Sustainability 44:26-34. https://doi. org/10.1016/j.cosust.2020.02.005

Cumming, G. S., J. Southworth, X. J. Rondon, and M. Marsik. 2012. Spatial complexity in fragmenting Amazonian rainforests: Do feedbacks from edge effects push forests towards an ecological threshold? Ecological Complexity 11:67-74. https://doi. org/10.1016/j.ecocom.2012.03.002

Cumming, G. S., and S. von Cramon-Taubadel. 2018. Linking economic growth pathways and environmental sustainability by understanding development as alternate social-ecological regimes. Proceedings of the National Academy of Sciences 115 (38):9533-9538. https://doi.org/10.1073/pnas.1807026115

Cunningham, S. C., R. Mac Nally, P. J. Baker, T. R. Cavagnaro, J. Beringer, J. R. Thomson, and R. M. Thompson. 2015. Balancing the environmental benefits of reforestation in agricultural regions. Perspectives in Plant Ecology, Evolution and Systematics 17 (4):301-317. https://doi.org/10.1016/j.ppees.2015.06.001

Curtis, P. G., C. M. Slay, N. L. Harris, A. Tyukavina, and M. C. Hansen. 2018. Classifying drivers of global forest loss. Science 361:1108-1111. https://doi.org/10.1126/science.aau3445

Dasgupta, S., B. Laplante, H. Wang, and D. Wheeler. 2002. Confronting the environmental Kuznets curve. Journal of Economic Perspectives 16(1):147-168. https://doi. org/10.1257/0895330027157

Decocq, G., E. Andrieu, J. Brunet, O. Chabrerie, P. De Frenne, P. DeSmedt, M. Deconchat, M. Diekmann, S. Ehrmann, B. Giffard, E. G. Mifsud, K. Hansen, M. Hermy, A. Kolb, J. Lenoir, J. Liira, F. Moldan, I. Prokofieva, L. Rosenquist, E. Varela, A. Valdés, K. Verheyen, and M. Wulf. 2016. Ecosystem services from small forest patches in agricultural landscapes. Current Forestry Reports 2:30-44. https://doi.org/10.1007/s40725-016-0028-x

DeFries, R. S., T. Rudel, M. Uriarte, and M. Hansen. 2010. Deforestation driven by urban population growth and agricultural trade in the twenty-first century. Nature Geoscience 3:178-181. https://doi.org/10.1038/ngeo 756

Dixon, P. 2003. VEGAN, a package of R functions for community ecology. Journal of Vegetation Science 14(6):927-930. https://doi. org/10.1111/j.1654-1103.2003.tb02228.x

Epstein, G., J. Pittman, S. M. Alexander, S. Berdej, T. Dyck, U. Kreitmair, K. J. Raithwell, S. Villamayor-Tomas, J. Vogt, and D. Armitage. 2015. Institutional fit and the sustainability of socialecological systems. Current Opinion in Environmental Sustainability 14:34-40. https://doi.org/10.1016/j.cosust.2015.03.005

Fahrig, L., V. Arroyo-Rodríguez, J. R. Bennett, V. BoucherLalonde, E. Cazetta, D. J. Currie, F. Eigenbrod, A. T. Ford, S. P. Harrison, J. A. G. Jaeger, N. Koper, A. E. Martin, J.-L. Martin, J. P. Metzger, P. Morrison, J. R. Rhodes, D. A. Saunders, D. Simberloff, A. C. Smith, L. Tischendorf, M. Vellend, and J. I. Watling. 2019. Is habitat fragmentation bad for biodiversity? Biological Conservation 230:179-186. https://doi.org/10.1016/j. biocon.2018.12.026 
Fearnside, P. M. 2005. Deforestation in Brazilian Amazonia: history, rates, and consequences. Conservation Biology 19 (3):680-688. https://doi.org/10.1111/j.1523-1739.2005.00697.x

Fletcher, R. J. Jr., R. K. Didham, C. Banks-Leite, J. Barlow, R. M. Ewers, J. Rosindell, R. D. Holt, A. Gonzalez, R. Pardini, E. I. Damschen, F. P. L. Melo, L. Ries, J. A. Prevedello, T. Tscharntke, W. F. Laurance, T. Lovejoy, and N. M. Haddad. 2018. Is habitat fragmentation good for biodiversity? Biological Conservation 226:9-15. https://doi.org/10.1016/j.biocon.2018.07.022

Geist, H. J., and E. F. Lambin. 2002. Proximate causes and underlying driving forces of tropical deforestation: tropical forests are disappearing as the result of many pressures, both local and regional, acting in various combinations in different geographical locations. Bioscience 52(2):143-150. https://doi.org/10.1641/0006-3568 (2002)052[0143:PCAUDF]2.0.CO;2

Haddad, N. M., L. A. Brudvig, J. Clobert, K. F. Davies, A. Gonzalez, R. D. Holt, T. E. Lovejoy, J. O. Sexton, M. P. Austin, C. D. Collins, W. M. Cook, E. I. Damschen, R. M. Ewers, B. L. Foster, C. N. Jenkins, A. J. King, W. F. Laurance, D. J. Levey, C. R. Margules, B. A. Melbourne, A. O. Nicholls, J. L. Orrock, D.X. Song, and J. R. Townshend. 2015. Habitat fragmentation and its lasting impact on Earth's ecosystems. Science Advances 1(2): e1500052. https://doi.org/10.1126/sciadv.1500052

Hansen, M. C., P. V. Potapov, R. Moore, M. Hancher, S. A. Turubanova, A. Tyukavina, D. Thau, S. V. Stehman, S. J. Goetz, T. R. Loveland, A. Kommareddy, A. Egorov, L. Chini, C. O. Justice, and J. R. G. Townshend. 2013. High-resolution global maps of 21st-century forest cover change. Science 342:850-853. https://doi.org/10.1126/science.1244693

Hansen, M. C., S. V. Stehman, P. V. Potapov, T. R. Loveland, J. R. G. Townshend, R. S. DeFries, K. W. Pittman, B. Arunarwati, F. Stolle, M. K. Steininger, M. Carroll, and C. DiMiceli. 2008. Humid tropical forest clearing from 2000 to 2005 quantified by using multitemporal and multiresolution remotely sensed data. Proceedings of the National Academy of Sciences 105 (27):9439-9444. https://doi.org/10.1073/pnas.0804042105

Henders, S., U. M. Persson, and T. Kastner. 2015. Trading forests: land-use change and carbon emissions embodied in production and exports of forest-risk commodities. Environmental Research Letters 10(12):125012. https://doi.org/10.1088/1748-9326/10/12/125012

Kasperson, J. X., R. E. Kasperson, and B. L. Turner II, editors. 1995. Regions at risk: comparisons of threatened environments. United Nations University Press, Tokyo, Japan.

Kassambara, A., and F. Mundt. 2017. factoextra: extract and visualize the results of multivariate data analyses. [Computer software.] [online] URL: https://rpkgs.datanovia.com/factoextra/ index.html

Koop, G., and L. Tole. 1999. Is there an environmental Kuznets curve for deforestation? Journal of Development Economics 58 (1):231-244. https://doi.org/10.1016/S0304-3878(98)00110-2

Kuznets, S. 1955. Economic growth and income inequality. American Economic Review 45:1-28.

Lamarche, C., S. Bontemps, T. De Maet, E. Van Bogaert, I. Moreau, C. Brockmann, M. Boettcher, G. Kirches, J. Wevers, and
M. Santoro. 2017. Land cover CCI product user guide version 2.0. UCLouvain-Geomatics, Brussels, Belgium. [online] URL: https://maps.elie.ucl.ac.be/CCI/viewer/download/ESACCI-LC-Ph2PUGv2 2.0.pdf

Laurance, W. F., A. K. M. Albernaz, G. Schroth, P. M. Fearnside, S. Bergen, E. M. Venticinque, and C. Da Costa. 2002. Predictors of deforestation in the Brazilian Amazon. Journal of Biogeography 29(5-6):737-748. https://doi.org/10.1046/ j.1365-2699.2002.00721.x

Le, H. D., C. Smith, J. Herbohn, and S. Harrison. 2012. More than just trees: assessing reforestation success in tropical developing countries. Journal of Rural Studies 28(1):5-19. https:// doi.org/10.1016/j.jrurstud.2011.07.006

Levin, S. A. 1992. The problem of pattern and scale in ecology. Ecology 73(6):1943-1967. https://doi.org/10.2307/1941447

Lin, J. Y., and D. Rosenblatt. 2012. Shifting patterns of economic growth and rethinking development. Journal of Economic Policy Reform 15(3):171-194. https://doi.org/10.1080/17487870.2012.700565

Lorena, R. B., and E. F. Lambin. 2009. The spatial dynamics of deforestation and agent use in the Amazon. Applied Geography 29(2):171-181. https://doi.org/10.1016/j.apgeog.2008.09.003

Lugo, A. E. 2002. Can we manage tropical landscapes? - an answer from the Caribbean perspective. Landscape Ecology 17:601-615. https://doi.org/10.1023/A:1021419815480

Lykke, L. E., C. W. J. Granger, E. J. Reis, D. Weinhold, and S. Wunder. 2002. The dynamics of deforestation and economic growth in the Brazilian Amazon. Cambridge University Press, Cambridge, UK. https://doi.org/10.1017/CBO9780511493454

MacArthur, R. H., and E. O. Wilson. 1963. An equilibrium theory of insular zoogeography. Evolution 17(4):373-387. https://doi. org/10.1111/j.1558-5646.1963.tb03295.x

Magliocca, N. R., E. C. Ellis, G. R. H. Allington, A. de Bremond, J. Dell'Angelo, O. Mertz, P. Messerli, P. Meyfroidt, R. Seppelt, and P. H. Verburg. 2018. Closing global knowledge gaps: producing generalized knowledge from case studies of socialecological systems. Global Environmental Change 50:1-14. https:// doi.org/10.1016/j.gloenvcha.2018.03.003

Mather, A. S. 1992. The forest transition. Area 24(4):367-379. [online] URL: https://www.jstor.org/stable/20003181

Mather, A. 2001. The transition from deforestation to reforestation in Europe. Pages 35-52 in A. Angelsen and D. Kaimowitz, editors. Agricultural technologies and tropical deforestation. CABI, Wallingford, UK. https://doi. org/10.1079/9780851994512.0035

Mather, A. S., and C. L. Needle. 1998. The forest transition: a theoretical basis. Area 30(2):117-124. https://doi.org/10.1111/ j.1475-4762.1998.tb00055.x

McGarigal, K., S. A. Cushman, and E. Ene. 2012. FRAGSTATS 44: spatial pattern analysis program for categorical and continuous maps. [Computer software.] University of Massachusetts, Amherst, Massachusetts, USA. [online] URL: http://www.umass. edu/landeco/research/fragstats/fragstats.html 
Meyfroidt, P., R. R. Chowdhury, A. de Bremond, E. C. Ellis, K.H. Erb, T. Filatova, R. D. Garrett, J. M. Grove, A. Heinimann, T. Kuemmerle, C. A. Kull, E. F. Lambin, Y. Landon, Y. le Polain de Waroux, P. Messerli, D. Müller, J. Ø. Nielsen, G. D. Peterson, V. Rodrigues García, M. Schlüter, B. L. Turner II, and P. H. Verburg. 2018. Middle-range theories of land system change. Global Environmental Change 53:52-67. https://doi.org/10.1016/j. gloenvcha.2018.08.006

Miller-Rushing, A. J., R. B. Primack, V. Devictor, R. T. Corlett, G. S. Cumming, R. Loyola, B. Maas, and L. Pejchar. 2019. How does habitat fragmentation affect biodiversity? A controversial question at the core of conservation biology. Biological Conservation 232:271-273. https://doi.org/10.1016/j.biocon.2018.12.029

Molotoks, A., E. Stehfest, J. Doelman, F. Albanito, N. Fitton, T. P. Dawson, and P. Smith. 2018. Global projections of future cropland expansion to 2050 and direct impacts on biodiversity and carbon storage. Global Change Biology 24(12):5895-5908. https://doi.org/10.1111/gcb.14459

Montero, P., and J. A. Vilar. 2014. TSclust: an R package for time series clustering. Journal of Statistical Software 62(1):1-43. https://doi.org/10.18637/jss.v062.i01

Murtagh, F., and P. Legendre. 2014. Ward's hierarchical agglomerative clustering method: Which algorithms implement Ward's criterion? Journal of Classification 31:274-295. https://doi. org/10.1007/s00357-014-9161-Z

Nagendra, H., J. Southworth, and C. Tucker. 2003. Accessibility as a determinant of landscape transformation in western Honduras: linking pattern and process. Landscape Ecology 18:141-158. https://doi.org/10.1023/A:1024430026953

Patiño, J., R. J. Whittaker, P. A. V. Borges, J. M. FernándezPalacios, C. Ah-Peng, M. B. Araújo, S. P. Ávila, P. Cardoso, J. Cornuault, E. J. de Boer, L. de Nascimento, A. Gil, A. GonzálezCastro, D. S. Gruner, R. Heleno, J. Hortal, J. C. Illera, C. N. Kaiser-Bunbury, T. J. Matthews, A. Papadopoulou, N. Pettorelli, J. P. Price, A. M. C. Santos, M. J. Steinbauer, K. A. Triantis, L. Valente, P. Vargas, P. Weigelt, and B. C. Emerson. 2017. A roadmap for island biology: 50 fundamental questions after 50 years of The Theory of Island Biogeography. Journal of Biogeography 44(5):963-983. https://doi.org/10.1111/jbi.12986

Perz, S. G. 2007. Grand theory and context-specificity in the study of forest dynamics: forest transition theory and other directions. Professional Geographer 59(1):105-114. https://doi.org/10.1111/ j.1467-9272.2007.00594.X

Perz, S., S. Brilhante, F. Brown, M. Caldas, S. Ikeda, E. Mendoza, C. Overdevest, V. Reis, J. F. Reyes, D. Rojas, M. Schmink, C. Souza, and R. Walker. 2008. Road building, land use and climate change: prospects for environmental governance in the Amazon. Philosophical Transactions of the Royal Society B 363:1889-1895. https://doi.org/10.1098/rstb.2007.0017

R Core Team. 2019. R: a language and environment for statistical computing. R Foundation for Statistical Computing, Vienna, Austria. [online] URL: https://www.R-project.org/

Schumpeter, J. A. 1983. The theory of economic development: an inquiry into profits, capital, credit, interest, and the business cycle.
Transaction Publishers, New Brunswick, New Jersey, USA. https://doi.org/10.4324/9781315135564

Solow, R. M. 1956. A contribution to the theory of economic growth. Quarterly Journal of Economics 70(1):65-94. https://doi. org/10.2307/1884513

Song, X.-P., M. C. Hansen, S. V. Stehman, P. V. Potapov, A. Tyukavina, E. F. Vermote, and J. R. Townshend. 2018. Global land change from 1982 to 2016. Nature 560:639-643. https://doi. org/10.1038/s41586-018-0411-9

Stern, D. I. 2004. The rise and fall of the environmental Kuznets curve. World Development 32(8):1419-1439. https://doi. org/10.1016/j.worlddev.2004.03.004

Swan, T. W. 1956. Economic growth and capital accumulation. Economic Record 32(2):334-361. https://doi.org/10.1111/j.1475-4932.1956. $\underline{\mathrm{tb} 00434 . \mathrm{x}}$

Treby, D. L., J. G. Castley, and J.-M. Hero. 2014. Forest conservation policy implementation gaps: consequences for the management of hollow-bearing trees in Australia. Conservation and Society 12(1):16-26. https://doi.org/10.4103/0972-4923.132122

Turner, B. L. II, S. C. Villar, D. Foster, J. Geoghegan, E. Keys, P. Klepeis, D. Lawrence, P. M. Mendoza, S. Manson, Y. OgnevaHimmelberger, A. B. Plotkin, D. P. Salicrup, R. R. Chowdhury, B. Savitsky, L. Schneider, B. Schmook, and C. Vance. $2001 a$. Deforestation in the southern Yucatán peninsular region: an integrative approach. Forest Ecology and Management 154 (3):353-370. https://doi.org/10.1016/S0378-1127(01)00508-4

Turner, M. G., R. H. Gardner, and R. V. O’Neill. 2001b. Landscape ecology in theory and practice: pattern and process. Springer, New York, New York, USA.

Warren, B. H., D. Simberloff, R. E. Ricklefs, R. Aguilée, F. L. Condamine, D. Gravel, H. Morlon, N. Mouquet, J. Rosindell, J. Casquet, E. Conti, J. Cornuault, J. M. Fernández-Palacios, T. Hengl, S. J. Norder, K. F. Rijsdijk, I. Sanmartín, D. Strasberg, K. A. Triantis, L. M. Valente, R. J. Whittaker, R. G. Gillespie, B. C. Emerson, and C. Thébaud. 2015. Islands as model systems in ecology and evolution: prospects fifty years after MacArthurWilson. Ecology Letters 18(2):200-217. https://doi.org/10.1111/ ele. 12398 
Appendix 1

Table S.1. Legends used in the LC maps. The time series data were grouped into the six broad land categories, i.e. cropland, forest, grassland, wetland, settlement and other land. The class 'other land' is further described as shrubland, sparse vegetation, bare area and water.

\begin{tabular}{|c|c|c|}
\hline Classes & LC value & Label \\
\hline Agriculture & $10,11,12$ & Rain-fed cropland \\
\hline Agriculture & 20 & Irrigated cropland \\
\hline Agriculture & 30 & $\begin{array}{l}\text { Mosaic cropland }(>50 \%) / \text { natural vegetation (tree, shrub, herbaceous cover) } \\
(<50 \%))\end{array}$ \\
\hline Agriculture & 40 & $\begin{array}{l}\text { Mosaic natural vegetation (tree, shrub, herbaceous cover) }(>50 \%) / \text { cropland } \\
(<50 \%)\end{array}$ \\
\hline Forest & 50 & Tree cover, broadleaved, evergreen, closed to open (>15\%) \\
\hline Forest & $60,61,62$ & Tree cover, broadleaved, deciduous, closed to open (> 15\%) \\
\hline Forest & $70,71,72$ & Tree cover, needle-leaved, evergreen, closed to open (> 15\%) \\
\hline Forest & $80,81,82$ & Tree cover, needle-leaved, deciduous, closed to open (> 15\%) \\
\hline Forest & 90 & Tree cover, mixed leaf type (broadleaved and needle-leaved) \\
\hline Forest & 100 & Mosaic tree and shrub (>50\%) / herbaceous cover $(<50 \%)$ \\
\hline Forest & 160 & Tree cover, flooded, fresh or brakish water \\
\hline Forest & 170 & Tree cover, flooded, saline water \\
\hline \multirow[t]{2}{*}{ Grassland } & 110 & Mosaic herbaceous cover $(>50 \%) /$ tree and shrub $(<50 \%)$ \\
\hline & 130 & Grassland \\
\hline Wetland & 180 & Shrub or herbaceous cover, flooded, fresh-saline or brakish water \\
\hline Settlement & 190 & Urban \\
\hline Other, & $120-122$ & Shrubland \\
\hline Sparse & 140 & Lichens and mosses \\
\hline Vegetation & $150-153$ & Sparse vegetation (tree, shrub, herbaceous cover) \\
\hline
\end{tabular}




\begin{tabular}{|l|l|l|}
\hline Bare area & $200-202$ & Bare areas \\
\hline Water & 210 & Water \\
\hline
\end{tabular}

Table S.2. Summary data for the economic variables, forest rents (\% GDP), agriculture (and forestry, and fishing) value added (\% of GDP), and HDI with forest cover for each island

\begin{tabular}{|c|c|c|c|c|c|c|}
\hline Island & \multicolumn{2}{|c|}{ Forest rents (\% of GDP) } & \multicolumn{2}{|c|}{$\begin{array}{l}\text { Agriculture, forestry, and } \\
\text { fishing, value added (\% of } \\
\text { GDP) }\end{array}$} & \multicolumn{2}{|c|}{ HDI } \\
\hline Name & 1992 & 2015 & 1992 & 2015 & 1992 & 2015 \\
\hline $\begin{array}{c}\text { Anadaman and } \\
\text { Nicobar }\end{array}$ & 0.614 & 0.302 & 26.67 & 16.174 & 0.44 & 0.63 \\
\hline Antigua and Barbuda & No data & No data & 1.803 & 1.6123 & No data & 0.77 \\
\hline Bahamas & No data & No data & 2.663 & 0.821 & No data & 0.80 \\
\hline Cuba & 0.231 & 0.084 & 12.427 & 3.835 & 0.66 & 0.77 \\
\hline Cyprus & 0.011 & 0.009 & 5.724 & 1.8629 & 0.74 & 0.86 \\
\hline $\begin{array}{l}\text { Dominican } \\
\text { Republic }\end{array}$ & 0.056 & 0.048 & 12.013 & 5.485 & 0.61 & 0.73 \\
\hline Fiji & 0.470 & 0.756 & 17.583 & 7.872 & 0.65 & 0.72 \\
\hline Haiti & 1.167 & 0.946 & 34.121 & 17.417 & 0.42 & 0.49 \\
\hline Indonesia & 1.318 & 0.523 & 19.521 & 13.493 & 0.53 & 0.70 \\
\hline Jamaica & 0.351 & 0.205 & No data & 6.309 & 0.65 & 0.72 \\
\hline Japan & 0.018 & 0.015 & No data & 1.114 & 0.82 & 0.91 \\
\hline Martinique & No data & No data & No data & No data & No data & No data \\
\hline Mauritius & 0.020 & 0.001 & 10.0127 & 3.154 & 0.63 & 0.79 \\
\hline Philippines & 0.58 & 0.265 & 21.821 & 10.260 & 0.6 & 0.70 \\
\hline Papua New Guinea & 3.771 & 2.711 & 25.979 & 17.457 & 0.39 & 0.54 \\
\hline Puerto Rico & No data & No data & 1.2128 & 0.827 & No data & No data \\
\hline Singapore & 0.001 & 0.000 & 0.197 & 0.0326 & 0.74 & 0.93 \\
\hline Solomon & 7.310 & 21.48 & 44.414 & No Data & No data & 0.55 \\
\hline Sri Lanka & 0.508 & 0.122 & 26.122 & 8.184 & 0.63 & 0.77 \\
\hline Taiwan & 0.001 & 0.002 & 21.329 & 8.422 & 0.52 & 0.74 \\
\hline
\end{tabular}




\begin{tabular}{|c|c|c|c|c|c|c|}
\hline Tasmania & 0.188 & 0.119 & 3.053 & 2.373 & 0.87 & 0.93 \\
\hline Vanuatu & 0.903 & 0.814 & 16.20 & 25.842 & No data & 0.60 \\
\hline Zanzibar & 11.114 & 3.994 & 44.704 & 26.746 & 0.37 & 0.52 \\
\hline
\end{tabular}

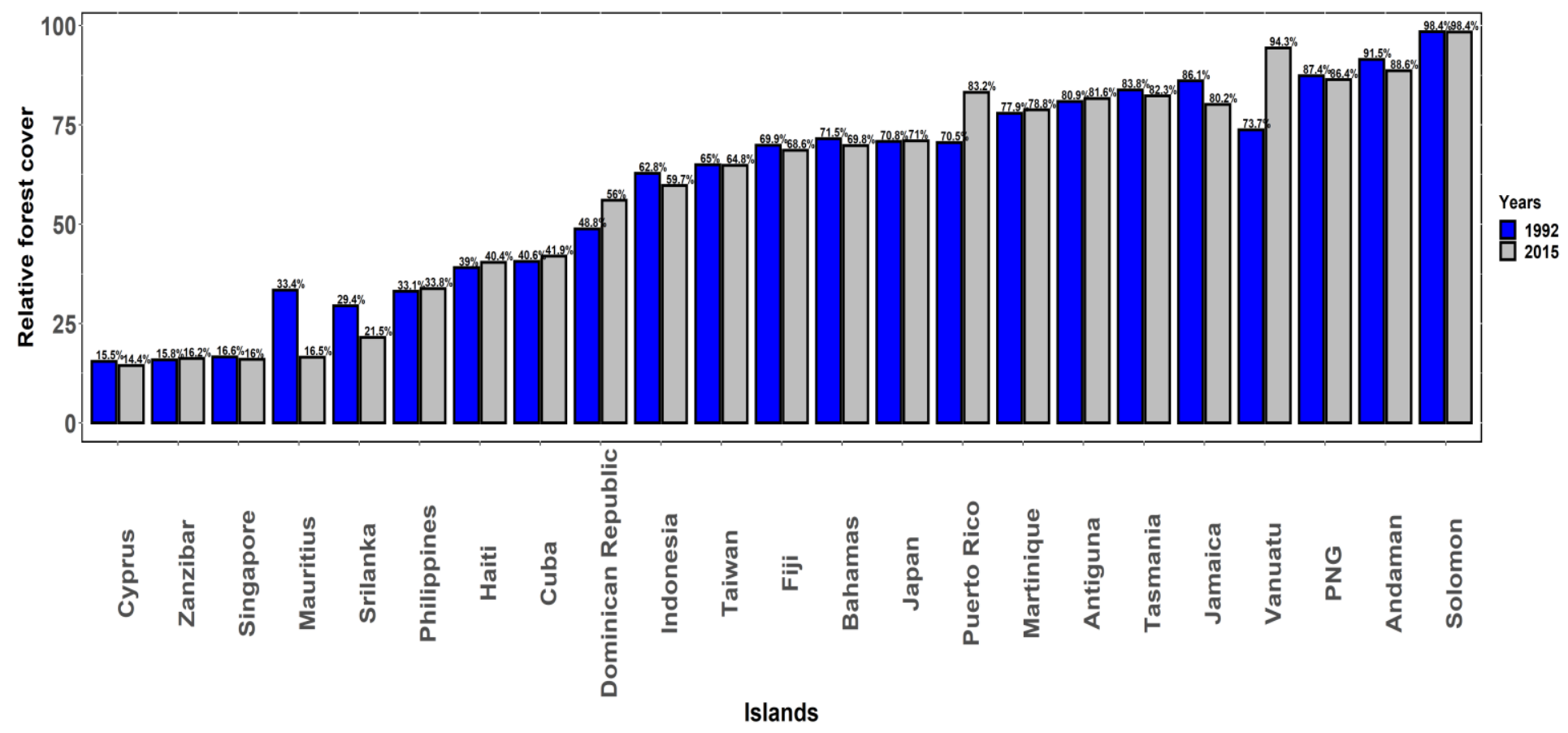

Fig. A.1 Forest relative cover for each island for the years 1992 and 2015 (used to determine percentage net forest change (Figure 1)). 